特 集

\title{
エ業材料としての高分子フィルム 写真用フィルム
}

はじめに

写真用フィルムは，ゼラチンをバインダーとし感光性

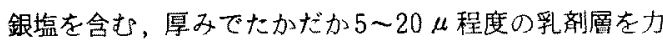
学的にささえる支持体としての役割をもっている。

又, その際, 柾水性のフィルムに親水性の乳㓢層は容 易には接着できず，接着性をだすための下塗層村与，あ しくは表面処理が必要よなる。更に写真として使われる 特の種々の要求を満たすためには，カールバランス，ア ンチルレーション性，アンチスタチック性等, 多くの機 能付与が必要である。本稿では写真用支持体としての概 説にあわせ，下塗，バッキング層としての必要機能及び どのような考え方でそれらが付与されるのかを紹介して 孙い。

\section{1. 写真用フィルムの歴史}

写真用支持体としては最初ガラスが使用されていたが 重く破損しやすく，加ざるという難点があった。しか し寸度安定性は極わてすぐれて扔り，特殊用途には現在 も使用されている。フレキシブルフィルムとしては1889 年になってはじぬて硝酸セルロース(以下NCと略)が害 用化され，卷物とする事が可能になり映画へと発展して いった。NCは写真用フィルムとして種々の観点よりす ぐれた性翼を有していたが、ニトロ基を含有するために 発火しやすく，映画館で上映中に火災が発生したり，保 存中に変質したフィルムが自然発火するトラブルが頻発 しだ”。この対策しして不燃性フィルムが研究され，也 ルロースジアセテート, セルロースアセテートプロピオ ネート等が実用化されたが，力学的強度と寸度安定性の 雨者完満たす点でNCにまさるすのはなかった。 セルローストリア七テート(以下, TAC と略)につい

Photographic Film Base

YUKIO SHINAGAWA

Ashigara Factory Technical Section of

No. 1 Production Department

FUJI PHOTO FILM CO., LTD.

富士写真フイルム(株)足柄工場第 1 製造部技術課
品川幸 雄

ては、これを溶かす溶戍が工業的にはなく，DOW がメ チレンクロライドの合成に成功してはじめて実用化され るようになった。 TAC は種々の点で NCをしのいでお り，1940年代にはTACへの切替が行われた。TACは， そのすぐれた性質ゆえに現在であ広く使われているが， 工業製図や地戍作成のための航空フィルム等の用途に対 しては寸度安定性が不十分である事は認識されていた。 その点を補うものとして1940年代後半になって次々上 登場してきた合成高分子が写真用フィルムとして検討き れた。ポリスチレン(PSt)， ポリエチレンテレフタレ 一ト(PET)，ポリカーボネート(PK)がその主たるお のであり，PSt，PKも一部実用化に迄至った。しかし， PSt は吸湿寸度安定性は良好であるが，熱処理でも結 晶性をあげられないために，熱に対する寸度安定性が覀 く，力学的にあ折れ曲がりによって，クレージングによ る白化を起してしまう等の欠点があり，又，PKも熱膨 張保数が大きい事，溶郕でクラッキングを起してしまう 等の久点があり，写真用フィルムのポスト TAC の主流 はPETとなっていった。

PET は，二軸延伸し熱固定してや机は，写真用フィ ルムとして非常にすぐれた性質を示す。TACに較へてて 力学的強度は顕著に大きく，寸度安定性むはるか伅良い。 そのため，フィルムを溥くしたいマイクロフィルムや， 寸度安定性加㦑しく要求される印剧用感材では, PET フィルムがTACに置き代ってきた。

しかしながらPETフィルムも万能ではなく，届折率 が高くアンチハレーションの点で難点がある事，溶剂で のスプライスができずテープスプライスが必要である等， クリアーできない点むあり，現在の写真用フィルムは， TAC と PET に二分されている現状である。この二種の フィルムの比較をする事は，写真用フィルム上して必要 な特性は何か，在如実に示寸事になる。以下，その観点 より述へるが，表1には，以上概説した写真用フィルム として検討されてきた支持体の一般性状をまとめて示し ておく。 
表 1 写真フィルム用ベースの一般性状

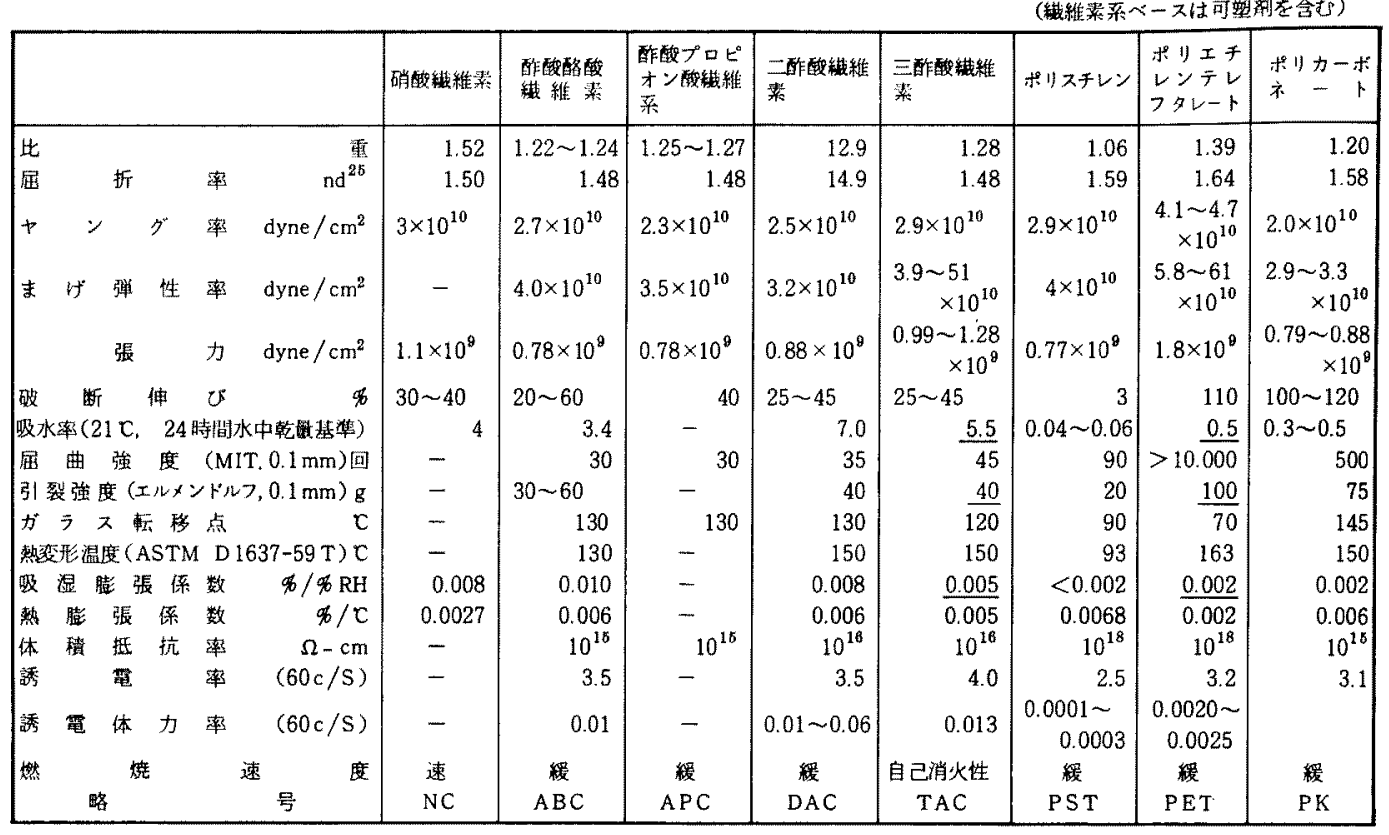

\section{TACよPETフィルムの比較}

両者で影著に異なる力学強度の差を表 2 に示す。特に 写真フィルムとして問題になる引裂に注目すると，いっ たん引裂加れた後，をれを伝播する力はPETはTACの 2〜3倍であるが，引裂くために最初に要する力はTAC の約 8 倍であり非常に差がある。TACフィルムは手で 引裂けるが，PETフィルムは困難である。との手で引 裂ける事が映画用フィルムの編集作業では必要な事があ り，スプライス性の䔡さと併せて，ての分野を TAC ᄀ イルムに䁚る一つの要因となっている。

勿諭，との強度ゆえに PETフィルムは，薄物フィル ムとして使用される。

次に届折率の点ではPETの方が高い。この事はPET フィルムをロールフィルム等に使用しようとする時に問 題になるライトパイピング性の点で不利である。ライト パイピングとは，フィルムの日中装填時などにエッジか ら入った光が，内部全反射によって侵入しかぷらせる現 象であり，乳剂㜥のゼラチンと写真フィルム素材の届折 率比によって決まるが, ゼラチンの屆折率 1.54 に対して PET 1.64 と大きく，TACでは 1.48 と小さく, PETで おきやすい事がわかる。このため PETでは必ず染料ね り込子等の防止策が必要となる。

又，体積抵抗率はPET $10^{18} \Omega / \mathrm{cm}, \operatorname{TAC} 10^{18} \Omega / \mathrm{cm}$ であり，PETの方が高く，発生した電荷は漏洩しにく
表2 $\mathrm{TAC} ・ \mathrm{PET}$ フィルムの機械的性質

\begin{tabular}{|l|l|l|}
\hline & \multicolumn{1}{|c|}{ TAC } & \multicolumn{1}{|c|}{ PET } \\
\hline $\begin{array}{r}\text { Tensile streng th at break } \\
\left(\mathrm{kg} / \mathrm{mm}^{2}\right)\end{array}$ & 12 & 20 \\
Tensile elongation at break (\%) & 25 & 140 \\
$\begin{array}{r}\text { Young 's modulus (c.g. s.) } \\
\text { Tear streng th (propagation) } \\
(\mathrm{g}-\mathrm{cm} / \mathrm{cm})\end{array}$ & 30 & $60 \sim 80$ \\
$\begin{array}{c}\text { Tear streng th (initiation) } \\
(\mathrm{kg} / \text { micron) }\end{array}$ & 3 & 25 \\
\hline
\end{tabular}

くスタチックマーク発生の危険性が大きい。

\section{TACフィルム}

TAC は融点 (約 $300 \mathrm{C}$ ) と分解温度が近いために溶融 製膜ではつくれず溶液製膜される。溶液製膜は他の方法 に比較する上生産性が劣り，エネルギーコストの点から も不利であるが，品質的には透明性，平面性のすぐれた フィルムをつくる事ができる。兒在，TACの製膜は世界 で娄数社しか行っていない。

図1には TACフィルム製造のフローダィアグラム を示し，以下若千の説明を加える。

原料の TAC フレークは、メチレンクロライドに若干 のアルコールを加えた溶波に溶解され，乙れに可塑剤を 添加して沪過するとドープと呼ばれる濃厚溶液ができる。 これを鏡面のようにみがかれたドラム表面，又はエンド 


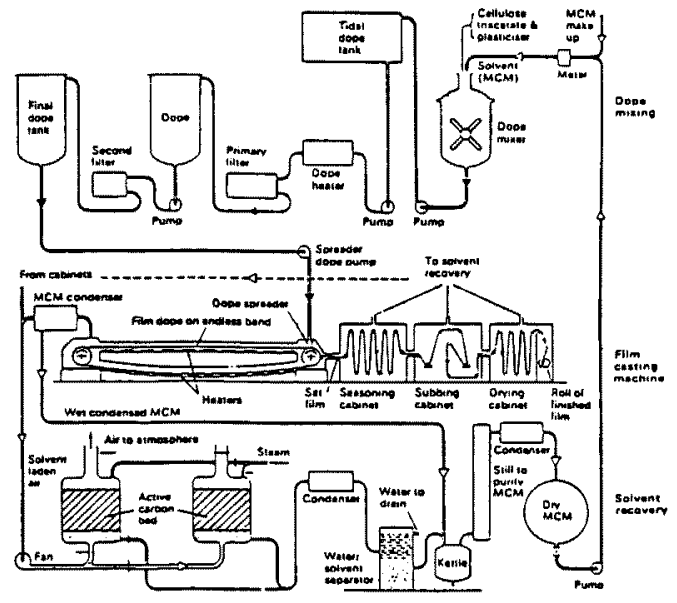

国 1 Flow diagram of triacetate base manufacture

レスバンドの表面に流延し，ある程度乾燥させ，自己支 持性をあたせた後に剥ぎ取る。この剥ぎ取りタイミング に上って可塑剂の表裹差分布，膜強度が大きく影響を受 け，非常に重要である。剥ぎ取られたフィルムにはある 程度乾燥された後に，写真乳剂層との接着性を出すため の下塗層や，後述する種々の機能付与のためのバッキン グ層が塗布される。

$\mathrm{TAC}$ フィルムの性質は，原料的には重合度，酢化度， 可塑剤の種類と量によって大きく変化する。

一般的には, 重合度が大きい程, 酢化度が大きい程, 機械的性質や耐熱性にすぐれ，寸度安定性が良い。写真 用として使用される酢化度は $60 \sim 62 \%$ 位であり，非常 に澉選されたセルロースが原料として用いられる。それ は写真用乳剂が非常に敏感で少しの不純物に対してあ反 応を示し，かぶり，减感などのトラブルに直結するから である。

可塑剂は，写真用として次の観点より選択される。(1) 水に抽出されにくい事(現像処理工程)，(2)沸点が高く蒸 気圷が低い事(乾燥工程)，(3)蹯水性である事(寸度安定 性)，(4)熱，光，化学薬品に対して安定である事(写真性) 等の観点を満たす可塑剂は少なく，世界の TACフィル ムメ一力で，数種類の可塑剤が単独又は組み合わされて 使用されているにすぎない。最专有名なものはトリフェ ニルフォスフエート(TPP)であり，有機溶剤性はよい が水に対する溶解度は極めて低く，䠅水性付与の点加ら あ広く用いられている。

\section{PETフィルム}

今さら述べる迄もなく良く知られた PET は，結晶性
高分子であり，二軸延伸を行い，熱処理をすると，微細 な配向結晶を生じ, 強度が著しく上昇し，熱的にも湿度 的にも寸度の安定したフィルムを得る事ができる。

写真用 PET フィルムの場合, 分子量, 約 20000 の乾 爆ペレットを押出し機により $280 \sim 300^{\circ} \mathrm{C}$ 亿加熱溶融し， 冷却ドラム上に押出し，縦及び横方向に各々，3〜4倍 の延伸をした後, 適度な熱固定をして巻取る事になる。 この際，延伸条件や熱固定条件がフィルムの機械的性質， 寸度安定性，平面性に大きな影響をおよぼす。

PETフィルムでは，TACでほとんど問題にならなか った光学的性質について述べなればならない。一つは PET ペレットその物が有する黄色の着色であり，その 原因はポリエンらしいと言われているが，まだ明確にな つていない。ペレットの再生利用を行うケースのように 熱履歷加增える上黄色味は強くなり，商品価䛧の低下に つながるし，又，柴外部の吸収が增大する事により印刷 感材では焼き付け時の感度低下を起す事がある。

通常用途では大きな問題にならない吸収が，写真用フ ィルムでは致命的になるケースもでてくる。

又，溶融製膜の宿命であるが，工程中に滞留部がある 之，熱分解を生じ，分子量低下や高分子量物生成が扰き る。乙れら変成物か流出すると，沦故障，スジ故障，着 色物故障之なるが，これらあ又，写真用フィルムでは致 命的であり，滞留物をなくす事が非常に重要である。

\section{5. 写其用フィルムとしての機能性付与}

踈水性である PET，TACフィルムに親水性の乳剂層 (ゼラチンバインダー)を直接塗布しても必要な接着力は 得ら机ない。写真フィルムの接着は乾燥時のみならず， 現像工程の中のアルカリや酸の水溶液中で乳剂層か膨潤 したゲル状態です強固な事が要求されるので後述するよ うに，下症層付与，表面処理等，種々の工夫がされる事 になる。

上記の乳剂層の接着の他に写真用フィルムには, 帯電 防止性, アンチハレーション性, カールバランス, 滑り 性, 耐傷性等, 多くの機能力゙要求され，図2 亿示すよう なバッキング層か設けられる。そこではバッキング層用 接着層古広義に下塑層上定義されている。

図2Aのようにベースの両面に下泾を付与する品種は レントゲンフィルム, 印刷用フィルム, カラーカットフ イルム等, シートとして用いられ，カールバランスが重 要なものがあげられる。図2Bのようにアルカリ可溶性 カーボンバック層を付与する品種は, 映画用フィルム， シングル 8 等, アンチハレーション性, 帯電防止性を強 く要求されるるのである。図 $2 \mathrm{C}$ のうに透明バック層 を設ける品種としては，間接レントゲンフィルム，航空 
A ぜラチンバック

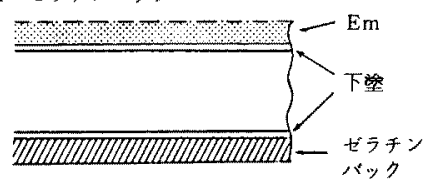

B カーボンレジンバック
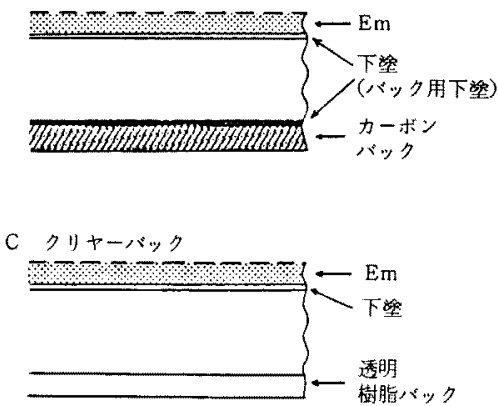

洞2

フィルム等があげられるが, 品種毎のニーズによってバ ッキング層の機能は干差万別のものとなる。

\section{6. 下 染 層}

$\mathrm{TAC}$ フィムの下叙は，初期には TACと良く接着す るポリマーを第一層しし，その上に同じポリマーを含む ゼラチン分散液を第二層として梁布した重穈下梁が用い られた。これら易接著性ポリマーとしてはNC, DACが 選択された ${ }^{3,4)}$

その後,サリチル酸によって分散したゼラチン，NC 分散液にメチレンクロライドを加え， TAC フィルムの 表面をエッチングする事により笚層で下筌する方法が見 いだされ，更にゼラチン分散液にグリセロールやホルム アルデ七ド等の硬膜剂を加える万法 ${ }^{5)}$ とて発展してい った。ゼラチン分散物の TAC ベースへのエッチングに よるアンカリングの概念を图 3 に模式的に示しておく。 又，表 $3^{6)}$ には，特許上り見る各社の下塗液組成を示 す。

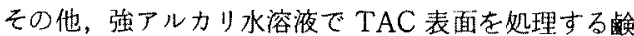

化法 ${ }^{7)}$ ，拱水マレイン酸共重合体等によるポリマ一下㬁 ${ }^{8)}$ む見られるが，TACの沉用溶剂での良膨潤性ゆえに， ゼラチン分散下染が王流となっている。

それに較べて PETフィルムでは，化学的に安定で汎 用溶剤に膨潤したり执かされないため，上述したゼラチ ン分散液の考え方では容舄に接着力が出せず，種々の方 法が検討されている。

初期に行われた試みは，TACの重層下塗上同様な発 想であり，PETと親和性が高く接着性の良いポリマー を第一層とし，第三畨には第一層ポリマーと乳剂層ゼう チンの㪼者に漞和性のある層を設ける考え方であった。 第一㬝ポリマーとしては，非晶性ポリエステル，程酢ビ 其重合体，ポリビニルアセタール等が選択され，第二層 ししては，ゼラチンあるいはゼラチンーNC 分散液が用 いられた。この似たあのを順次ならへてていって接着力を 得ようと言う考え方は，PETフィルムが写真用として 使われはじめた年代の各社共通のものであっだ。

PETフィルムは，各種表面処理によって比較的容易 に表面活性化する事が出来る。コロナ放歶では極く表面 であるがカルボニル基等が導入され PETフィルムは自 着性を示すようになる。紫外線処理では極く表面の活性 化効果に加六, 内部 $10 \mu$ 程度迄，酸化分解による分子量 低下が起る事が報告されている

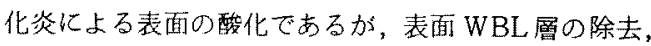
表面粗化，表面結晶化屯伴っていると言われる。
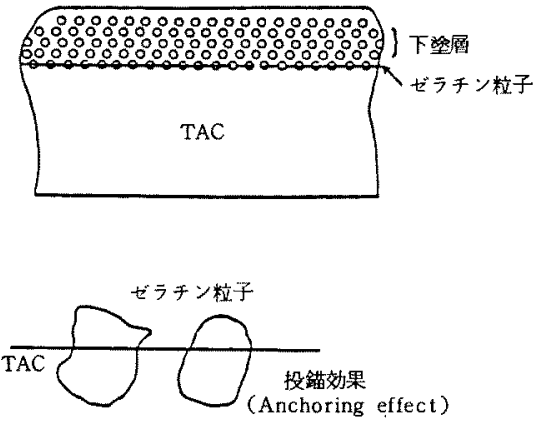

図 3 ベース下塗層よの密着機構

表 3 ゼラチン下塑液組成

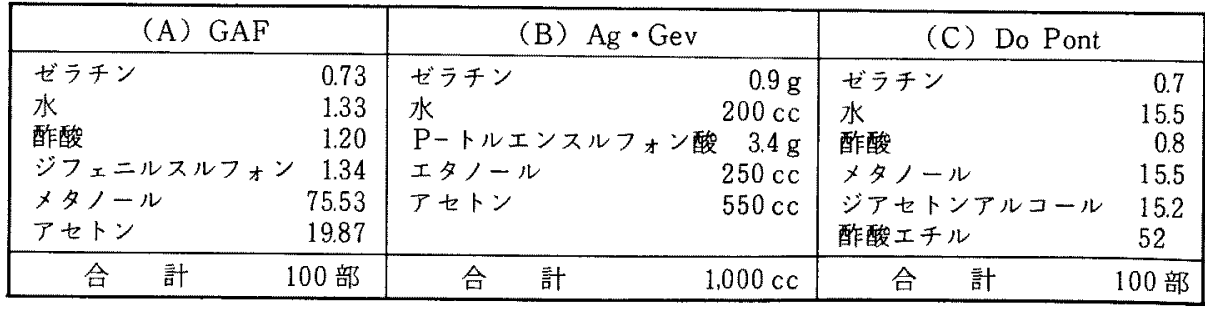


以上の様な表面処理 PET フィルムに，ゼラチン分散 液による下然をすると、コロナ放電では接着力がでない が, 後二者ではよく接着し，とのPET の系でもゼラチ ンのアンカリングが関与している事が示㖫されている。 次に水系ラテックスを用いたポリマー下烝があるが非常 に有効である。塩化ビニリデン系共重合体ラテックスを PETフィルムの末延伸時江㙰布し，つてて延伸後に第 二層のゼラチンを嫄布する方法は ${ }^{11)}$ ，代表的なものであ り，その他，塩ビ系共重合体，ブタジェン系共重合体等 す用いられる。てれらポリマーはいずれもゼラチンに較 ベると弾性率は低い事が重要であり，又，共重合体成分 の中にアクリル酸等の酸成分を有する事が特徵的であ る。

\section{7. バッキング層}

写真フィルムに塗布された乳剂層の吸湿量は図4のと おり、フィルムより1オーダー高いため比表裹の寸度差 を生じカールを生じる事になる。

表裹の寸度変化と生じるカールの関係は图5のように 因式化され，Umberger ${ }^{12)}$ にっって(1)式のように定量

$$
C=\frac{1}{\rho}=\frac{6\left(E_{2} / E_{1}\right)\left(a_{1} / a_{2}\right)\left(\beta_{2}-\beta_{1}\right)}{1+\left(a_{1} / a_{2}\right)\left\{4\left(E_{2} / E_{1}\right)-1\right\}}\left(H_{\mathrm{c}}-H_{\mathrm{o}}\right)
$$

(夫々の記号については図5を参照)

化された。そこでは，フィルムと付与された層の厚みと 弾性率がきく事がわかる。ゼラチンを主体とした乳剂層 付与の場合, 70〜100\%の湿度ではゼラチン弾性率は低 く、フィルム自体でカールが決まってしまうが，低湿で は乳戍層の奇与が大きくなってくる。

写真フィルムのカールは，自動現像機での搬送性や， 撮影時，烧き付け時の局部的なピントのボケ等のトラブ ルとなる困った現象である。

カールバランスのためにバッキング層としてゼラチン 層を付与するのは，乳剤層は八ロゲン化鑹等を含むので 完全なバランスはとれないが，最も有効な方法である。

ハレーションと呼ばれる現象は，乳剂面を通過して写 真フィルムの中に入って来た光が，バック面で反射して

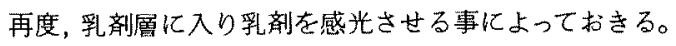

図6にその様子を模式的に示すが，ひどい時にはできあ がりの像の輸郭がばけてしまうが，そて迄いかなくてあ， シャープネスの低下を招き，写真性能を大きく損ってし まう。この現象は屈折率の高いPET フィルムでより大 きな問題となってくる。

その防止策としては，図6にみるように乳剂の最下層 へのハレーション防止層付与, フィルム自体の染色やマ ット剂混入，染料本しくはカーボンブラックを含有した バッキング層の付与があげら机る。

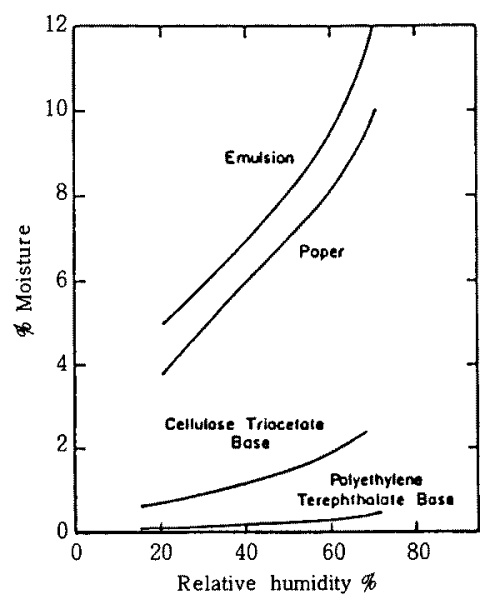

図 4 各湿度に招りる平衡水分量

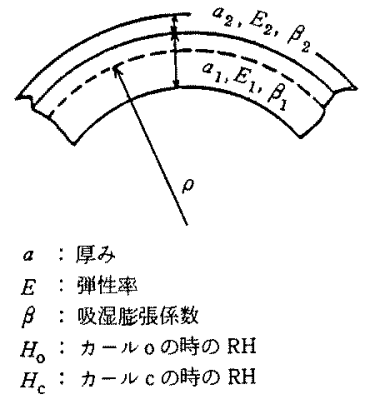

図 5 フィルムのカール

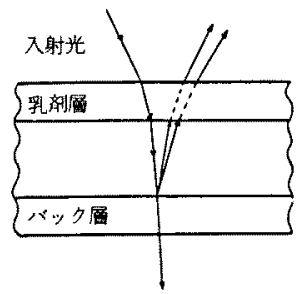

防止方法

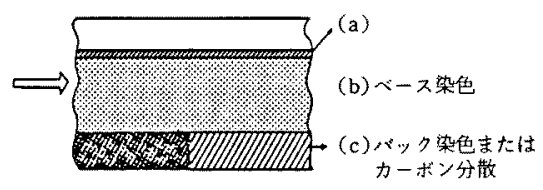

图6ハレーションの発生モデルと防止方法 
帯電防止は，バッキング層の最も重要な機能の一つで ある。特に最近の乳剂の感度アップ, 高速度撮影化, 迅 速现像処理化の状況の中では，帯電防止されていない写 真フィルムではひどいスタチックマーク発生となり，写 真画像は見るに耐えないるのとなってしまう。

带電防止の基本的考元は，まず発電させない事，そし て発電されても放電压に達する前に䨟電させてしまう事， もしくは電荷を安定化してしまい放電させない事である。 詳細はのへないが，発電させないためには問題となる場 所の材質之帯電列をあ执せる事が種々の帯電王調節剂を 用いて行われる。そして漏洩させるためには導電性ポリ マー，金留酸化物等をバッキング風に含有させ，表面電 気抵抗を下げる。一般に帯電防止のためにはこれらの考 えを組み合せ使用するが，最近では放電しても放電光が 画像形成する乳郕層に達する前佂吸取してしまうような 試み手併用されてきた。

バッキング層の機能としてはざらに滑り性付与, 酎偤 性付与, 耐ブロッキング性付与等, 詳細すると枚挙にい 上まがなく割爱するが，以上の様な機能が写真感材によ る様々なニーズや，既に述へてきたTAC，PETフィル 么の特性を踏まえ千差万別な組み合せで付与され，満足 すべき写真フィルムになる事になる。

おわりに

駆け足で写真用フィルムを概説したか，支持体として
のフィルムの状態と機能付与のための下治㬝，バッキン グ㬝によって発琴する性質は独立しているか心印象を与. 元大感があるが，最終的に発現してくる性質は实につィ ルムの状態の影響老強く受ける。製膜，流延条件の放密 な規定なくしては最終品質の一定化は困難である。

PET, TACフィルムとあ写具フィルムとして必要な 状態コントロールには，微妙な“生むのを取扱う”感覚 が必要であり，その一定化はまだ今後の課題として残っ ている部分が多い。

\section{文献}

1) J.M. Calhoun, "An Improved Safety Picture Film Support" in Progress in Photography $1940 \sim 1950,130$, The Focal Press.

2) E. G. Couzens, "Film Casting Process"

3) Brit. 546,825

4) U.S. $2,939,806$

5) E. G. Couzens, "Film Casting Process"

6) U.S. $2,461,474$, Brit. 990,477 , Belg. 666,385

7) 特公昭 40-2276

8) DP $1,040,898$

9) P. Blais et al., J. Appl. Polym. Sci., 17, 1895 ('73)

10) U.S. $2,704,382$

11) U.S. $2,779,684$

12) Photogr. Sci. Eng., 1, 69 ('57)

(昭和 60 年 4 月 15 日受理) 